\title{
THE QUALITY OF NURSING CARE OF THE FRAIL AGED IN SELECTED INSTITUTIONS IN EASTERN CAPE AND NATAL
}

\section{INTRODUCTION}

During 1988-89 a research project was undertaken to establish standards and criteria for the nursing care of the frail aged in institutions in South Africa, and to develop and test an instrument to measure the quality care, based on these standards. A part of this project was to investigate the actual quality of care achieved in selected institutions, to establish norms for comparison, and to investigate which factors influence the quality or care.

The results of the first part of the study are published in a separate article. This article will deal only with the survey of the quality of care. The objectives of this study were:

* To establish the quality of nursing care of frail aged residents in selected institutions in the Eastern Cape and Natal.

* To establish the influence on the quality of care of the following factors:

- the level of care needed (dependency level of residents);

- the staffing levels

- the size of the unit.

\section{ETHODOLOGY}

\section{The Instrument:}

The instrument is described fully in another article (Uys and Hunt, 1990). It consists of three sections, one dealing with the whole institution, the other with the frail aged unit(s), and the third with the individual residents. The inter-rater reliability of this instrument was found to be 0,916 for the first two sections and 0,792 for the last. There were also some indication of internal consistency. Content validity of the standards were established by two groups of nurses, and construct validity of the instrument was based on its ability to differentiate between different institutions.

The instrument contains structure, process and outcome standards and criteria, and data is collected from records, through interviews and by observation. It takes about six hours to complete the data collection in one institution.

\section{The sample:}

It was decided for the sake of convenience to do the study in the Eastern Cape and Natal,

\author{
Noelle B. Hunt, Leana R. Uys
}

\begin{abstract}
An investigation was undertaken to establish standards for the care of the frail aged and to develop an instrument to measure this care. In this process the care in 12 institutions was monitored. In general, the care was found to be of good quality, with an average of $74,3 \%$, but there are residences where the percentage is up to $10 \%$ lower. The influence of some internal and external factors on the quality of care were investigated.

\section{Opsomming}

' $n$ Ondersoek is onderneem om standaarde vir die verpleegsorg van verswakte bejaardes in tehuise vas te stel, en ' $n$ instrument te ontwikkel om bereiking van hierdie standaarde te meet. In hierdie proses is die sorg in 12 tehuise nagegaan. Oor die algemeen was die gehalte van die sorg goed, met ' $n$ gemiddeld van $74,3 \%$, maar daar was tehuise waar die persentasie tot 10\% laer was. Die invloed van sekere interne en eksterne faktore op die gehalte van die sorg, is ook nagegaan.
\end{abstract}

with the first area supplying only the rural institutions, and the latter only the urban institutions for the study. The sampling frame and sample is set out in Table 1. The institutions were stratified according to size, and a proportionate sample of institutions were selected from the strata at random through random number tables. Only one institution drawn refused to participate, and another was drawn.

In the second step of the sampling, five residents in the larger homes and three in the smaller ones were conveniently chosen to be included in the study. No resident refused to take part.

In total 12 institutions, 16 units for the frail aged, and 52 out of the possible 728 residents $(7 \%)$, were included in the sample. The institutions represented 11 different funded agencies. Data collection took place over a period of four months, and was done by three registered nurses.

\begin{tabular}{|c|c|c|c|c|c|c|}
\hline \multicolumn{7}{|c|}{$\begin{array}{l}\text { TABLE } 1 . \\
\text { SAMPLING; FRAME OF INSTITUTIONS WITH } \\
\text { FRAII, AGFD UNITS. }\end{array}$} \\
\hline \multirow[b]{3}{*}{$\begin{array}{l}\text { Smal } \\
\text { (less than } 25 \\
\text { residents) }\end{array}$} & \multicolumn{3}{|c|}{ Hestern Cape } & \multicolumn{3}{|c|}{ Natal } \\
\hline & Number & Ratio & Sample & Number & Ratio & Sample \\
\hline & 0 & $\mathbf{0}$ & $\mathbf{0}$ & 7 & 1 & 1 \\
\hline $\begin{array}{l}\text { Medium } \\
\text { (25 to } 75 \\
\text { residents) } \\
\text { Large }\end{array}$ & 10 & 2 & 6 & 11 & 2 & 2 \\
\hline $\begin{array}{l}\text { (more than } 75 \\
\text { residents) }\end{array}$ & 4 & 1 & 2 & 6 & 1 & 1 \\
\hline Total & 14 & & 8 & 24 & & 4 \\
\hline
\end{tabular}

\section{RESULTS}

1. Comparison of Institutions:

The quality of care in all the institutions is summarized in Table 2 . While the average quality of care on the Institution

Questionnaire was 76,7\% and that on the Unit Questionnaire $75,5 \%$, the average on the Resident Questionnaire was only $71 \%$. It would seem therefore that the care given to individuals needs greater improvement than the facilities in general or the unit programmes. The percentages are generally high, but there are individual homes where the care is significantly lower.

Table 2

QUALTTY OF CARE (IN \% AGE) IN INSTITUTIONS, UNITS AND FOR RESIDENTS

\begin{tabular}{|c|c|c|c|}
\hline & $\begin{array}{l}\text { INSTTTUTION } \\
x\end{array}$ & $\underset{x}{\text { UNIT }}$ & $\begin{array}{c}\text { RESIDENT } \\
x\end{array}$ \\
\hline 1 & 71,1 & 73,8 & 70,9 \\
\hline 2 & 78,8 & 81.2 & 67,0 \\
\hline 3 & 77,9 & 72,0 & 66,0 \\
\hline 4 & 75,4 & 59,2 & 55.6 \\
\hline 5 & 76.6 & 79.6 & 68.2 \\
\hline 6 & 77,6 & 81,5 & 68,5 \\
\hline 7 & 60.2 & 64.7 & 68,9 \\
\hline 8 & 70,2 & 61,7 & 66,8 \\
\hline 9 & 75,6 & 72,2 & 66.5 \\
\hline 10 & 81,7 & 82.5 & 74.6 \\
\hline 11 & 85,1 & 75.9 & 86.7 \\
\hline 12 & 90.7 & 96,5 & 92,8 \\
\hline Average & 76,7 & 75.5 & 71,0 \\
\hline
\end{tabular}

\section{The Residents}

The nursing care of 52 frail residents was assessed, requiring evaluation of 124 items of care, grouped into 8 categories. It is not proposed in this account to discuss results obtained on each item, but rather to highlight some particular aspects of care which appear to be especially important. The mean quality 
of nursing care of residents at $71 \%$ was reasonably good, but the variation between the 12 institutions ranged from $66,0 \%$ to 92,8\%.

Eight broad categories of care related to details of the nursing assessment of residents on admission to the institution, which were the on-going nursing record, care given at mealtimes, components of care in regard to residents' elimination status, personal hygiene, mobility and respiration, provision of comfort, pain relief, sleep and rest, and factors pertaining to orientation, stimulation and communication.

Recording of aspects of the nursing assessment of residents on admission was problematical as most records gave no indication as to the time of first charting of data; the general impression of the quality of initial assessment is one of sketchiness. In conversation with staff in the rural areas, it was found that often they had known the residents prior to admission to the institution; in the urban areas, staff knew quite to lot about residents who were visited frequently and it was clear that staff knew considerably more about residents than was charted in the records. This situation leaves residents vulnerable to sudden changes of staff and cessation or absence of visitors.

Of approximately 34 separate details considered necessary for a satisfactory initial nursing assessment of residents, only 9 items were recorded as assessed in more than half the sample of residents. Aspects of care generally considered essential for the drawing up if an individualised nurse care plan were not necessarily appraised. For example, the residents' accustomed daily routine was assessed in $2 \%$ of the sample, interests and hobbies in $4 \%$ of sample, customary dietary patterns in $10 \%$ sample. Factors directly related to the preservation of urinary continence, such as elimination patterns, levels of activity and abilities were underassessed.

individual residents was present in $71,4 \%$ cases but in more than half these cases, there was no indication that these needs had been recorded by a registered nurse, and in only $30 \%$ cases was there evidence that these records were kept up-to-date

Assessment of care at mealtimes showed that in most instances, the resident was seated comfortably, that provision was made for special dietary needs and that adapted eating utensils were available. The major problem relating to mealtimes was that insufficient time was allowed to foster independent eating; it was found that $64,7 \%$ of residents are fed by nursing staff at meals.

Almost a third of the residents assessed were incontinent of urine which compares reasonably well with other studies.

Brocklehurst (1978) considered 6 surveys of the prevalence of incontinence among hospitalised geriatric patients and found a range of $24-40 \%$ among men and $24-46 \%$ among women; Trichard et al. (1982) found that of 100 consecutive admissions to 30 homes for elderly Whites in Cape Town, $23 \%$ were incontinent. Of the $30,4 \%$ incontinent residents in the present study, only $12,5 \%$ were catheterised which reflects an encouraging trend; catheter care in general appeared good. Nevertheless, of the 17 incontinent patients, only 6 had this problem documented in the nursing record, and baseline data giving the pattern and timing of incontinent episodes was recorded for only 1 resident.

Oedema which may cause problems in regard to skin breakdown was present in $16 \%$ residents and dehydration in the elderly person notably may be perplexing and indeed was a difficulty for fieldworkers; the number of dehydrated residents, in fact, may have been higher than recorded. The provision of sufficient daily intake of fluids ( 2 litres is recommended) for the elderly person is one of the most difficult nursing charges, calling for art, skill and persuasion. Certainly a really

\section{TABLE 3.}

SELECTED DETAILS SHOWING QUALITY OF TOTAL. INITIAL NURSING ASSESSMENT OF 52 RESIDENTS

Nursing detail
1. Names, addresses, visiting habits of close friends
2. State of vision \& hearing
3. Psychiatric history
4. Religious affiliation
5. Orientation to time, place \& person
6. Prescribed medication
7. Prostheses necessary
8. Involvement of resident community
9. Mental effect
10. Condition of skin
11. Hydration status
12. Comfort, pain status
13. TPR \& BP
14. Dietary pattern
15. Elimination pattem
16. Nutritional state including weight
17. Activity patterms
18. Interests \& hobbies
19. Preferred daily routine

$\begin{array}{r}\text { \% age } \\ \text { recorded }\end{array}$

60,8
58,8
56,9
52,9
52,9
52,9
51,0
51,0
50,0
37,3
23,5
23,5
33,3
9,8
37,3
35,3
31,4
3,9
2,0
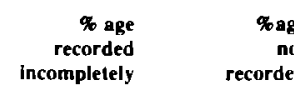

oge
not \%age
not avai
or no
applicable

9,8

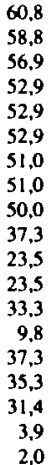

between them but these usually were acquired outside the institution. Residents hair, nails and mouths were well cared for but the presence of corns in 4 residents and in-grown toe nails in 5, emphasises again the need for special chiropody services for the old person which was available in 8 of the 15 units observed. Uncomfortable, painful feet may be a potent factor in preventing optimum activity levels. Nails were clean but in $35,7 \%$ residents the nails were too long.

Assessment of the mobility status of residents showed that $9(16 \%)$ residents were bedridden, that only 1 of these residents received planned passive exercises twice daily and that none of them obtained chest physiotherapy. Immobility adds to nursing workload, as nurses are well aware, but the shoulder or Australian lift which is known to cause less strain on the lifter's backs (Stubbs and Osborne, 1979, Hill, 1986) was seen to be used to lift only 3 of the 9 bedridden residents. More positive observations related to the use of appropriate beds, residents position in bed, changing of position frequently, safe use of bed apparatus and comfortable bedclothes. All residents were seen to be dressed appropriately for the weather.

Nursing response in relation to adequate attention paid to complaints of pain was problematical; of 13 patients for whom pain could be a reality, it was judged that 7 $(12,5 \%)$ of them received appropriate attention.

Geriatric nursing is not easy; it is demanding labour intensive work requiring skilled observation, assessment, planning and delivery of care. The sample of 53 residents required a great deal of careful nursing input; almost a third of them were incontinent, almost a fifth of them were confused, most residents were not bedfast but all required assistance with mobilising. As most workers in the geriatric field point out, it is easier to nurse an old frail person in bed than it is to help them move from bed to chair to bathroom and dining room. It is also often easier to wheel a person in a wheelchair than it is to help them walk which is a trap hardpressed staff fall into all too commonly. Nevertheless, of the 4 items which were considered to affect the work load significantly i.e. the number of bedfast and chairfast residents, the correlation of workload and quality of care was low at 0,03 .

The quality of the residents' social life, his ability to communicate effectively and the provision of aids to his orientation are challenging components of the total calibre of care rendered. Claims made on staff to meet and compensate for the sometimes extreme physical frailty of residents can cause important aspects of psycho-social care to take second place. For example, nearly a quarter of the observed residents were not using effective spectacles, almost a half did not go to the dining-room for meals, approximately one fifth did not have a bedside table within reach and on the appropriate side.

Selected details of items evaluated in 15 institutions as relevant to the residents social life and are given in Table 4.

It was observed that nurses were kind and polite to residents', this is the least one would the quality of the total nursing assessment of residents. This table includes the 9 items which were recorded in more than $50 \%$ of residents, as well as other notable details, a knowledge of which allows the nurse to plan rational and appropriate care.

An on-going nursing record, detailing the current needs and problems pertaining to good variety of drinks should be provided. The present study indicates that fluid intake was inadequate in $75 \%$ cases; indeed, only in the daily diet.

Personal hygiene of residents was assessed and aspects of hair, skin, hand and foot care was recorded. On most cases this was acceptable; four patients had 5 pressure sores 


\begin{tabular}{|c|c|c|c|c|}
\hline \multicolumn{5}{|c|}{ SELECTED DETALLS OF ASPECTS OF RESIDENT'S SOCIAL LIFE IN IS UNITS } \\
\hline Detail & $\underset{\substack{\text { Recorded } \\
\text { present }}}{\text { }}$ & $\begin{array}{c}\% \\
\text { Recorded } \\
\text { present but } \\
\text { incomplete }\end{array}$ & $\begin{array}{c}\% \\
\text { Recurded } \\
\text { absent }\end{array}$ & 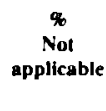 \\
\hline 1. Residents addressed individually & 100 & - & . & \\
\hline 2. Hairdressing \& barbering available to all & 100 & - & . & \\
\hline 3. Celebration of binthdays \& special events & 100 & . & - & \\
\hline 4. Encouragement of open visiting & 80 & 13 & 6 & \\
\hline 5. Institution owns pets & 53 & 13 & 33 & \\
\hline 6. Registered nurse observed in unit & so & 21 & 29 & \\
\hline $\begin{array}{l}\text { 7. Daily routine follows normal times \& allows for } \\
\text { variation }\end{array}$ & 48 & 47 & 7 & \\
\hline 8. Suff seen chatling to residents & 46 & 31 & 23 & \\
\hline 9. Evening entertainment provided & 40 & 7 & 53 & \\
\hline 10. OTganised programme \& recreational activities & 27 & 20 & 53 & \\
\hline 11. Organised programme of social stimulation & 27 & 13 & 6) & \\
\hline $\begin{array}{l}\text { 12. Continuous reality orientation implemented for } \\
\text { some residents }\end{array}$ & 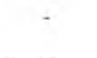 & 7 & 86 & 7 \\
\hline 13. Social interaction between residents stimulated by staf & 25 & & 75 & \\
\hline
\end{tabular}

expect. Aids to socialisation do not abound and attention to psycho-social needs of these institutionalised old people lagged behind attention to physical needs.

It is hoped that these instruments, to be seen as aids in the evaluating of standards of nursing care for the elderly in frail-care units, be distributed as widely as possible to all ose concerned in the provision of this case. The instruments are by no means difficult to use and should be helpful in drawing nurses' attention to specific areas of care which will be seen to be inadequate.

\section{The Institutions and Units.}

"The ergonomically-organised environment - that is, furniture and equipment which promotes and permits desirable activities to be performed without stress and strain, is now generally recognised as a fundamental requirement of al phases of treatment and care of geriatric patients." (Norton, McLaren and Extan Smith 1975).

This observation remains true and yet few studies of the physical environment in which the frail elderly are nursed have found enough attention paid to appropriate design and equipment. (Norton 1970. Wells 1980)

TABLE 5 gives a selection of details observed in the institutions studied pertaining to the environment. Attractive comfortable yrooms were present in 11 institutions and residents were observed to spend much time in them; 4 institutions had no dayroom which must be considered unacceptable. Only 1 institution did not have a diningroom. Many institutions did not provide inexpensive but useful aids to comfort and stimulation such as footstools, clocks and night-lights.

Bathrooms for the frail elderly ideally should be purpose-buili; many of the problems seen in this area were the result of buildings not having been designed for this purpose. The difficulty and inconvenience of nursing in situations whereby lavatories and bathrooms are not large enough to accommodate a wheelchair-bound patient and an attendant (and have doors opening inwards, all too often) or whereby a bath is not accessible on 3 sides, are too well-known to require further discussion.

Cheaper pieces of equipment were not available in many instances. A good, easily available variety of design as regard bedpans and urinals help both patient and nurse, but most institutions did not offer this. The reason mysterious; given the high frequency of hip surgery and arthritis in the elderly, one would consider that modified toilet seats are a basic necessity. Non-slip bathmats are cheap and usually allow old people to feel safe when bathing, but not all institutions had these in evidence. Armchairs were not always seen to be suitable for the needs of the residents in that sometimes these were too hard, too low or did not have adequate head support.

The most dedicated and caring nurse needs suitable equipment to help her give that care, but nurses for too long have been noted for a misguided patience in coping with what is to hand; it may be, too, that they are unaware of the variety of aids and equipment which are on the market. Norton (1970) and Wells (1980) both point out that what seems to be lacking is the nurses' inability to make precise statements of practical nursing problems based on study and analysis, followed by skilled presentation of problems at for the absence of raised toilet seats is administrative level.

\section{Conclusion}

In this study some excellent examples of the nursing care of the frail aged was observed. Nevertheless, a detailed study of individual items shows that definite areas of concern exist. It is recommended that institutions use these instruments as a means of improving care and not judging it.

\section{Acknowledgement}

This research was supported by a grant from the HSRC.

The assistance of the staff and residents of all the homes we visited, are greatly appreciated We want to thank the following people for their assistance at different stages of the research:

Mrs. L. Coetzee (SANA), (MRC),

Ms. J. Ueckermann (Frere College of Nursing).

\section{REFERENCES}

l. Nonon D (1970) By accident or design? A study

of equipment development in relation to basic nursing problems. Edinburgh. E \& $\mathrm{S}$ Livingstone.

2. Wells T. (1980) Problems in geriatric nursing care. Edinburgh. Churchill Livingstone.

3. Brocklehursı J.C. (1978) Textbook of geriatric medicine and gerontology. Edinburgh. Churchill Livingstone.

4. Trichard L.P., Bow A., Gillis L.S. (1982) Elderly persons in old-age homes. A medical, psychiatric and social investigation. South African Medical Journal 61, 17, 624-7.

5. Stubbs D.A. \& Osborne C.M. (1979) How to save your back. A comparison between the nursing profession and the construction industry. Nursing (1st series) June, 1979. 116 24.

6. Hill I. (1986) Towards safer lifting practice in (ed) Tiemey A.J. Clinical Nursing Practice. Edinburgh. Churchill Livingstone

Leana R. Uys. D. Soc. Sc. U.O.F.S. Professor Department of Nursing, University of Natal Durban

Noelle Hunt. M. Soc. Sc. U.N. Senior Lecturer. Department of Nursing, University of Natal:
Durban
TABLE. 5.

SELECTED DETAILS OF THE PHYSICAL. ENVIRONMENT IN 15 INSTITUTIONS FOR THE FRAIL, ELDERLY.

\begin{tabular}{|c|c|c|c|}
\hline Detuil & $\begin{array}{c}\% \\
\text { Present }\end{array}$ & $\begin{array}{c}\% \\
\text { Present with } \\
\text { reservation }\end{array}$ & $\begin{array}{c}4 \\
\text { Absent }\end{array}$ \\
\hline 1. Footstools available & 40 & 20 & 40 \\
\hline $\begin{array}{l}\text { 2. Clocks visible } \\
\text { a }\end{array}$ & 47 & 6 & 47 \\
\hline 3. Handrails in corridor & 87 & 7 & 7 \\
\hline 4. Non-slip foor surfaces & 53 & 7 & 40 \\
\hline 5. Lavatory accessible for wheel chair \& attendants & 53 & 20 & 27 \\
\hline 6. Raised lavatory seats & 7 & 13 & 80 \\
\hline 7. Variety of urinals \& bedpans available & 47 & & 53 \\
\hline 8. Bath accessible on 3 sides & 67 & 20 & 13 \\
\hline 9. Non-slip bath mats available & 73 & & 13 \\
\hline 10. Bathroom door opens outwards & 13 & 7 & 80 \\
\hline 11. Mirrors in bachroom & 13 & 87 & \\
\hline 12. Monkey chains on beds where necessary & 13 & 7 & 47 \\
\hline 13. Bedcradles available & 67 & 7 & 27 \\
\hline 14. Hoists available & 47 & : & 53 \\
\hline 15.Adequate sluicing facilities & 47 & . & 53 \\
\hline 16. Communal rooms have large labels & 33 & 13 & 47 \\
\hline
\end{tabular}

